\title{
THE RELATIONSHIP OF SCOUT EXTRACURRICULAR ON THE STUDENTS' DISCIPLINE
}

\author{
Nureva $^{1}$, Ahmad Tohir ${ }^{2}$ \\ ${ }^{1}$ STKIP Al Islam Tunas Bangsa \\ ${ }^{2}$ STKIP Al Islam Tunas Bangsa \\ 11nureva.2981@gmail.com, ${ }^{2}$ ahmadtohir182@gmail.com
}

\begin{abstract}
This study aims to determine the relationship between scout extracurricular activities on student discipline. This research is quantitative descriptive. The population in this study were all students who joined the Scout extracurricular at SDN 2 Way Huwi, namely 24 students. The research sample was taken using a Total sampling technique, so that a sample of 24 students was obtained. Data collection techniques are observation, interviews, and questionnaires. Data analysis techniques used the correlation Pearson product-moment with the help of the SPSS program. Based on the results of research and discussion, it can be concluded that there is a positive and significant relationship between scout extracurricular activities and student discipline in SDN 2 Way Huwi with a significance value $(0,000<0.05)$. Based on the results and discussion, it can be concluded that there is a positive and significant relationship between scout extracurricular activities and student discipline in SDN 2 Way Huwi with a significance value $(0,000<0.05)$. Student discipline must be considered because discipline is the initial key to the formation of other characteristics for students, the discipline taught in scouting activities has an important role in shaping students. Discipline in scouting activities is shown by students by always being present in scouting activities on time so that students can be role models for others.
\end{abstract}

Keywords: discipline, scout extracurrucular, student

\begin{abstract}
Abstrak
Penelitian ini bertujuan untuk mengetahui hubungan antara ekstrakurikuler pramuka terhadap kedisiplinan siswa. Penelitian ini merupakan penelitian deskriptif kuantitatif. Populasi dalam penelitian ini ialah seluruh siswa yang mengikuti ekstrakurikuler pramuka di SDN 2 Way Huwi sebanyak 24 siswa. Sampel penelitian diambil menggunakan teknik Total Sampling, sehingga diperoleh sampel berjumlah 24 orang siswa. Teknik pengumpulan data yaitu observasi, wawancara, dan angket. Teknik analisis data menggunakan korelasi pearson product moment dengan bantuan program SPSS. Berdasarkan hasil penelitian dan pembahasan, dapat disimpulkan bahwa terdapat hubungan yang positif dan signifikan antara ektrakurikuler pramuka dengan kedisiplinan siswa di SDN 2 Way Huwi dengan nilai signifikansi $(0,000<0,05)$. Kedisiplinan siswa memang harus diperhatikan karena kedisiplinan merupakan kunci awal pembentukan krakter yang lainnya bagi siswa, kedisplinan yang diajarkan dalam kegiatan pramuka memiliki peranan penting dalam membentuk siswa. Disiplin dalam kegiatan kepramukaan ditunjukkan siswa dengan selalu hadir dalam kegiatan kepramukaantepat waktu sehingga siswa pun bisa menjadi teladan bagi yang lainnya.
\end{abstract}

Kata Kunci: disisplin, siswa, ekstrakurikuler pramuka

\section{INTRODUCTION}

Education is basically all forms of activities of a learning process regarding knowledge, skills, and habits carried out by some people which will be passed on to the next generation. Education is a process of changing attitudes and behavior of a person or group of people through teaching and training efforts, while teaching or training is a process, method, act of teaching or training (Departemen Pendidikan Nasional, 2008). 
Building smart education starts from discipline, discipline that is applied by a student without realizing it will get very valuable benefits from the discipline that is applied. Discipline reflects behavior that obeys and complies with applicable rules, norms or ethics. Examples of undisciplined are skipping school and being late for school. It can be seen from this example that lack of discipline can be detrimental to others and especially to oneself. With education it is expected that students can build this nation into a more disciplined nation, respected by other countries without leaving the norms prevailing in society (Ulwiyah \& Praditasari, 2017).

Education is not just an academic aspect, many things can be taught, for example education in an activity or education that is concerned with the character of students. Many activities can be used as a forum for developing student character, one of the activities is Boy Scout extracurricular activities. Scout extracurricular is currently included in the 2013 curriculum as a compulsory extracurricular, the scout movement can function as a forum for coaching and developing the younger generation. The implementation is adjusted to the conditions, interests, and development of the Indonesian nation and society (Nuh, 2013).

Based on the results of an interview with the Principal of Way Huwi State Elementary School 2, scout extracurricular was required from grade 3 to grade 6 . It was even included in the learning activities of the school. This is because scouting activities teach students to become disciplined humans.

Previous research conducted by Prihanawati \& Hidayah (2018) with the title the effect of participating in scout extracurricular activities on the independence of fifth grade students of SD Negeri Cibuk Lor Seyegan Sleman in the 2017/2018 school year. The results showed that there is a positive and significant influence on the activity of extracurricular scouts on the independence of students of grade V SD Negeri Cibuk Lor Seyegan Sleman with a positive coefficient value of independence. This can be shown on the value of determinant coefficient (R2) of 0.409 , tcount of 3.429 and significance value of 0.003 . Because the significance value shows the number $<0,05$ then it can be concluded that the activity follows extracurricular scout have positive effect on independence. Then, research conducted by (Trianawati et al., 2013) which was entitled planting the value of responsibility through scouting extracurricular activities at SMP Negeri 13 Semarang. The results showed that the various responsibilities of the instilled through scouting in SMP Negeri 13 Semarang is the responsibility of self, responsibility for others, responsibility for nature and responsibility to God Almighty. The method used to instill responsibility is with the purification method value (giving advice, and awarding punishment / reward), an exemplary method (exemplary builder), method of active 
students (giving tasks and achievements SKU and SKK). Supporting factor is the attitude, knowledge and experience possessed by the builder, self-awareness and motivation of students in participating in extracurricular scout, funds, facilities and infrastructure that support the activities, the support of parents and the support of the surrounding community. Inhibiting factor is the lack of student interest in the scouts, the influence of friends who invite students to play truant and weather factors. Because someone has examined the attitude of independence and the value of responsibility, this research examines the extracurricular relationship with disciplinary attitudes.

\section{Scout Extracurricular}

According to Asmani (2012) the function of extracurricular activities is the development of students' independence and happiness which is useful for themselves, their families, and society. The same thing was also expressed by Wiyani (2013) which stated that the function of extracurricular activities itself was to develop the potential, talents and interests of students optimally and to foster independence and happiness which would later be useful for themselves and those around them.

The Scout Movement aims to educate Indonesian children and youth. Using the basic principles of the Scout education method, the implementation of which is adapted to the interests and development of the nation. The activity aims to make young people have; high mental and good morals, have noble character, uphold mutual cooperation in their environment; high intelligence and have volunteerism in devoting energy in the form of actions; have skills that are ready to be given to foster siblings. Scout extracurricular activities are educational processes in the form of activities that are fun for young people or students aiming to form a skilled, tough, loving homeland, responsible, and self-sacrificing attitude in accordance with dasa dharma and tri satya (Bahri \& Fibrianto, 2018)

Mario (Al Azizi, 2018) in the Scout Movement there is a scout code of honor consisting of promises called satya and moral provisions called dharma. Scout Satya is used as a personal binder to voluntarily practice it and is used as a starting point to enter the Scouting Education process. Darma Pramuka serves as a means of achieving the goals of Scouting Education whose activities encourage participants to be united with the community, democratic attitude, mutual respect, and a sense of togetherness and mutual cooperation. Scouting education has the goal of developing the potential of students as individuals and independent community members, 
who are ready to help others, be responsible and committed. So with this scouting education it is hoped that it can produce good young people.

\section{Discipline}

According to Tu'u (2004) discipline is a condition that is created and formed through a process of a series of behaviors that show the values of obedience, obedience, loyalty, orderliness, and attachment. In line with that, Pratiwi (2020)states that Discipline is one of the means in the effort to establish an orderly personality in doing something, discipline can also be in the form of time, in carrying out activities and others. According to Narwanti (2011) writes that discipline is an act that shows obedient and orderly behavior in various rules and regulations. In line with the opinion of Aqib (2012), discipline is an action that shows an orderly and obedient behavior in various rules and regulations.

School discipline is closely related to the craft of students in school and in learning. Discipline applied by the school affects the attitude of students in learning and their sense of responsibility as a student in school. Discipline of students in a school is also influenced by the discipline of all school staff including the principal and teachers. Therefore, for students to be disciplined, the teacher and other staff must also be disciplined (Slameto, 2003). According to Sofyan (2013), discipline concerns the vigor of a business and meeting the right time center target. This means discipline in work and time discipline.

Discipline is an action that shows order and complies with various rules and regulations. Discipline means an attitude that shows to help someone in facing various challenges and demands that exist in their environment. Discipline can also be interpreted as a condition that is responsible, orderly and obedient in carrying out their duties and obeying rules without coercion or through self-awareness that they have wholeheartedly and seriously. Discipline is an orderly and orderly state that must be possessed by students at school, without any violations made and detrimental either directly or indirectly (Handoko, 2016).

The character of discipline can be formed in various ways, one of which is to impose sanctions or penalties for any mistakes. These sanctions or penalties must contain an element of education so that learners in addition to having a deterrent effect also get lessons from any mistakes made. The formation of disciplinary character is the process of providing guidance to students to be able to become fully human beings and be able to face the challenges of the times and technology that is increasingly large (Supiana et al., 2019). 


\section{METHOD}

This research is quantitative descriptive. This type of research is correlation. The population in this study were all students who joined the scouts extracurricular at SDN 2 Way Huwi, namely 24 students. The research sample was taken using a total sampling technique, so that a sample of 24 students was obtained. Data collection techniques are questionnaires. Data analysis techniques used the correlation pearson product-moment with the help of the SPSS program. The hypothesis of this research:

$\mathrm{H}_{0}$ : There is no significant relationship between scout extracurricular and students' discipline $\mathrm{H}_{\mathrm{a}}$ : There is a significant relationship between scout extracurricular and students' discipline

\section{RESULTS AND DISCUSSION}

\section{Results}

The results of this study consisted of independent variables namely scout extracurricular (X) and dependent variables namely discipline (Y). Based on the results of the bivariate correlation test calculations using the Pearson correlation, obtained data as follows:

Table 1. Results of Pearson Correlation Analysis

\begin{tabular}{lllr}
\hline & & $\begin{array}{l}\text { Scout } \\
\text { Extracurricular }\end{array}$ & Discipline \\
\hline Scout Extracurricular & Pearson Correlation & & 1 \\
& Sig. (2-tailed) & & .904 \\
& N & 24 & .000 \\
Discipline & Pearson Correlation & .904 & 24 \\
& Sig. (2-tailed) & .000 & 1 \\
& N & 24 & 24 \\
\hline
\end{tabular}

Based on the table above, the correlation between scout extracurricular and student discipline is 0.904 . This shows that there is a strong relationship between scout extracurricular activities and student discipline. Furthermore, the significance of the correlation coefficient test is used to test whether the relationship that occurs is valid for the population or not. The testing steps are as follows:

1. Determine the hypothesis

$\mathrm{H}_{0}$ : There is no significant relationship between scout extracurricular and students' Discipline

$\mathrm{H}_{\mathrm{a}}$ : There is a significant relationship between scout extracurricular and students' discipline 
2. Determine the level of significance

Test using a 2-tailed test with a significance level of $a=5 \%$.

3. Testing Criteria

$\mathrm{H}_{0}$ is accepted if the significance $>0,05$

$\mathrm{H}_{0}$ is rejected if the significance $<0,05$

4. Compare significance

The significance value is $0,000<0,05$, then $\mathrm{H}_{0}$ is rejected.

5. Conclusion of the test

Because the significance value $(0,000<0.05)$ then $\mathrm{H} 0$ is rejected, meaning that there is a significant relationship between scout extracurricular and student discipline. Because the correlation coefficient is positive, scout extracurricular is positively and significantly related to student discipline.

\section{Discussion}

Based on the results of the study, showed that there is a positive and significant relationship between scout extracurricular activities and student discipline at Way Huwi 2 Public Elementary School, South Lampung Regency. The results of this study are supported by research conducted by Rahman \& Anggrianti (2020), Scout Extracurricular has an effect on student discipline in all students in SMA Negeri 8 Kota Serang. The success of scout extracurricular activities in the experimental group is because students more easily understand and extracted scout extracurricular values that can apply student disciplinary attitudes such as coming to be on time, trained in leadership attitudes, trained for nationalism attitudes, maintaining school infrastructure and adhering to school rules. In addition, the research results of Adlya et al (2020) stated that based on the results of the research, there is a significant contribution of self control to students' discipline which is $34.8 \%$ with a significance of 0,000 . Thus, self control gives a significant impact to students' discipline. This finding is based on data analysis score which $\mathrm{r}$ score is 0.590 ; means there is a strong relationship between self control and students' discipline. Therefore, the more someone has strong self control, the better their ability in improving and building their discipline behavior.

Scout extracurricular is an extracurricular activity which is now required in schools as a process to shape character and shape student disciplinary behavior both at school and outside of school. Scout extracurricular activities at school now in its application have referred to the 2013 curriculum, so that once a week at school there are scout extracurricular activities. The 
application of scouts at school does not always run smoothly, many students lack the discipline to take part in extracurricular scouts at school. In addition, the process of learning activities in schools today, we can find a lot of student discipline that is increasingly diminishing. Therefore in the new curriculum that is in school has to require the scout extracurricular as forming the character of discipline that must be followed by students in addition to that good character can also support and shape the way of thinking of good students so that students' learning achievement in school becomes better. To achieve this goal, activities carried out in the school environment and outside the school to be shown as a process to strengthen student character so that it has a strong discipline character and has a strong Pancasila spirit. Through scout education will lead to a sense of help, responsibility, and have a personality both in school and outside of school (Jatmiko et al., 2020).

Scout extracurricular goals as an inseparable to realize national goals, as stated in the opening of the 1945 Constitution, namely "Protect all Indonesian people and all Indonesian spilled blood and realize public welfare, educate the nation's life and participate in carrying out world order based on lasting peace, independence and justice social". Scout activities can also provide valuable provisions for the creation of a strong young generation. Because, this extracurricular activity is able to educate children in forming discipline. Being disciplined is very necessary for the realization of a good learning process. Learning with directed discipline can avoid feeling lazy and arouse students 'enthusiasm in learning, which in turn will be able to increase students' learning abilities. Discipline is the key to success and success. Therefore scout extracurricular activities are very important so that students are accustomed to being educated with a disciplined attitude (Dhahirah et al., 2017).

The character of discipline is an important thing that must be instilled in students. Discipline means obeying and obeying something that has been agreed upon. One of the scout extracurricular scouting has an important role in improving the discipline character of students. Scouting activities do not only study lines, semaphores or ciphers, but in scout extracurricular activities, there are various types of education taught, one of which is religion, health, the environment, social activities and so on. Scout extracurricular also teaches students the importance of being punctual in their daily activities. On time is a simple example that needs to be instilled early on with students. If students are accustomed to carrying out various activities in a timely manner, there will be a growing nature of awareness without even being instructed, students have realized that this is a necessity that needs to be carried out. The impact of extracurricular activities to improve the character of students' discipline through 
extracurricular activities can also be seen through the reduced level of student violations. In addition, the concrete evidence is that students are accustomed to implementing and complying with the rules that are made, the level of discipline of students also increases in terms of daily activities of students such as being on time, obeying existing regulations and cultivating queuing in various activities (Supiana et al., 2019). Student discipline must be considered because discipline is the initial key to the formation of other characteristics for students, the discipline taught in scouting activities has an important role in shaping students. Sulistyowati (2001), suggests that an indicator of a student can learn well, he must be disciplined, especially discipline in the following matters: discipline in keeping the study schedule, discipline in overcoming all the temptations that will delay learning time, self-discipline alone to be able to foster a willingness and enthusiasm for learning both at school such as obeying the rules, as well as discipline at home such as regularly studying, being disciplined in maintaining physical condition to keep it healthy and fit by eating regularly and nutritionally and exercising regularly.

Discipline in scouting activities is shown by students by always being present in scouting activities on time so that students can be role models for others. This is supported by a schedule of scouting activities carried out after school so that students are ready for school before the activity begins. Even in scouting activities, students show a disciplined attitude by carrying out assignments on time in accordance with the agreement with the Scout coach. Discipline is obedience to respect and implement a system that requires people to comply with applicable decisions, orders and regulations. In other words, discipline is the attitude of obeying the rules and regulations that have been set in a selfless manner. Discipline is very important for students, discipline is not only to run all the rules in accordance with the time but to increase a high level of success. For example time discipline, a student who runs activities with discipline. He tends to respect the time and work on assignments according to the time set. Discipline in learning, students will share learning schedules effectively, so that in carrying out learning activities, students can divide which ones are prioritized. For this reason students are required to make discipline a culture of success. In cleanliness is also seen when students are disciplined in disposing and managing waste to be more useful (Kharisma \& Suyatno, 2018). 


\section{CONCLUSION}

Based on the results and discussion, it can be concluded that there is a positive and significant relationship between scout extracurricular activities and student discipline in SDN 2 Way Huwi with a significance value $(0,000<0.05)$. Student discipline must be considered because discipline is the initial key to the formation of other characteristics for students, the discipline taught in scouting activities has an important role in shaping students. Discipline in scouting activities is shown by students by always being present in scouting activities on time so that students can be role models for others

\section{ACKNOWLEDGMENTS}

Thank you to all STKIP Al Islam Tunas Bangsa academics and SD Way 2 Huwi who have supported this research so that this research can be carried out and process well.

\section{REFERENCES}

Adlya, S. I., Yusuf, A. M., \& Effendi, M. (2020). The Contribution of Self Control to Students' Discipline. Journal of Counseling and Educational Technology Vol. 3(1), 1-5. https://doi.org/10.32698/0791

Al Azizi, N. Q. U. (2018). Kegiatan Ekstrakurikuler Kepramukaan Terhadap Pendidikan Karakter Kedisiplinan. Jurnal Pendidikan Luar Sekolah Vol. 12(2), 40-50.

Aqib, Z. (2012). Pendidikan Karakter Di Sekolah Membangun Karakter Kepribadian Anak. Bandung: Yrama Widya.

Asmani, J. M. (2012). Buku Panduan Internalisasi Pendidikan Karakter di Sekolah. Yogyakarta: Diva Press.

Bahri, S., \& Fibrianto, A. S. (2018). Hubungan Kegiatan Ekstrakurikuler Pramuka Dengan Tingkat Religiusitas Siswa SMA Negeri 1 Tangen (Perspektif Teori Sistem Sosial Talcott Parsons). Jurnal Sosiologi Agama Vol. 12(1), 67-84. http://dx.doi.org/10.14421/jsa.2018/121-04.67-84

Departemen Pendidikan Nasional. (2008). Berbagai Pendekatan Dalam Proses Belajar Mengajar. Jakarta: Bumi Aksara.

Dhahirah, S. A., Elly, R., \& Awaluddin. (2017). Pengaruh Kegiatan Ekstrakurikuler Pramuka Dalam Kurikulum 2013 Terhadap Kedisiplinan Siswa Kelas V di SD Negeri 10 Banda Aceh. Jurnal Ilmiah Pendidikan Guru Sekolah Dasar Vol. 2(2), 92-102.

Handoko, T. H. (2016). Manajemen. Yogyakarta: BPFE.

Jatmiko, T. A., Supriyanto, H. A., \& Nurabadi, A. (2020). Hubungan Keikutsertaan Ekstrakurikuler Pramuka Dengan Tingkat Kedisiplinan Siswa. JAMP: Jurnal Administrasi Dan Manajemen Pendidikan Vol 3(1), 11-18. 
Kharisma, C., \& Suyatno. (2018). Peran Guru Dalam Menanamkan Karakter Disiplin Siswa di Sekolah Dasar Negeri Bleber 1 Prambanan Sleman. Jurnal Fundamental Pendidikan Dasar Vol. 1(2), 131-139.

Narwanti, S. (2011). Pendidikan Karakter. Yogyakarta: Familia.

Nuh, M. (2013). Peraturan Menteri Pendidikan dan Kebudayaan Republik Indonesia Nomor 81A Tahun 2013 Tentang Implementasi Kurikulum. Kemdikbud.

Pratiwi, S. I. (2020). Pengaruh Ekstrakurikuler Pramuka Terhadap Karakter Disiplin Siswa SD. Edukatif: Jurnal Ilmu Pendidikan Vol 2(1), 62-70.

Prihanawati, D. R., \& Hidayah, N. (2018). Pengaruh Keaktifan Mengikuti Ekstrakurikuler Pramuka Terhadap Kemandirian Siswa Kelas V SD Negeri Cibuk Lor Seyegan Sleman Tahun Ajaran 2017/2018. Jurnal Fundamental Pendidikan Dasar Vol 1(1), 35-44. https://doi.org/10.12928/fundadikdas.v1i1.68

Rahman, A., \& Anggrianti, D. (2020). Pengaruh Ekstrakurikuler Pramuka Terhadap Disiplin Siswa (study Expost Facto). Jurnal Pelita Bumi Pertiwi Vol 4(1), 16-26.

Slameto. (2003). Belajar dan Faktor-Faktor yang Mempengaruhinya. Jakarta: Rineka Cipta.

Sofyan, S. (2013). Psikologi Pendidikan. Bandung: Alfabeta.

Sulistyowati, S. (2001). Cara Belajar Yang Efektif dan Efisien. Pekalongan: Cinta Ilmu.

Supiana, Hermawan, A. H., \& Wahyuni, A. (2019). Manajemen Peningkatan Karakter Disiplin Peserta Didik Melalui Kegiatan Ekstrakurikuler. Jurnal Islamic Education Manajemen Vol. 4(2), 193-208.

Trianawati, P., Rachman, M., \& Sumarto, S. (2013). Penanaman Nilai Tanggungjawab Melalui Ekstrakurikuler Kepramukaan di SMP 13 Semarang. Unnes Civic Education, Vol . 2(2), $67-76$.

Tu'u, T. (2004). Peran Disiplin Pada Perilaku dan Prestasi Siswa. Jakarta: Grasindo.

Ulwiyah, N., \& Praditasari, S. (2017). Pengaruh Kegiatan Kepramukaan Terhadap Disiplin Siswa di Madrasah Tsanawiyah Darul Ulum Bandung Diwek Jombang Tahun Pelajaran 2016-2017. Jurnal Pendidikan Islam Vol. 1(2), 235-257.

Wiyani, A. N. (2013). Konsep, Praktik, dan Strategi Membumikan Pendidikan Karakter di SD. Yogyakarta: Ar-Ruzz Media. 